\title{
The Role of Non -State Actors in Foreign Policy: Impact of Interest Group in Algeria on Morocco's Leaving OAU
}

\author{
JAMAL AIT LAADAM* \\ School of International Public Affairs SIPA, Jilin University, 2699. Changchun, P.R. China. \\ * E-mail of the corresponding author: Jimyfive555@yahoo.com
}

\begin{abstract}
The Western Sahara recognition by OAU has caused Morocco unprecedentedly withdrawal from its African organization. Thus this conflictual territory of Sahara has been an unchallengeable case file in the UN tasks of the dispute between several actors at different times since the Spanish granted the territory to Morocco in 1975. This paper illustrates how Algeria has utilized the non-state actor in Western Sahara to weaken Morocco's policy through its territory on the one hand and reshape Morocco's foreign policy decisions on the other. Yet, Algeria's involvement in the Western Sahara dispute has a long- term perspective especially in geopolitical and economic terms not only in North Africa but also in the entire continent.
\end{abstract}

Keywords: Western Sahara, Non -State Actors, Organization of African Unity. Algeria.

DOI: $10.7176 / \mathrm{JAAS} / 58-10$

Publication date:September $30^{\text {th }} 2019$

\section{Introduction}

In 1984 following the recognition of Western Sahara by the Organization of African Unity (OAU), the Kingdom of Morocco officially withdrew its membership from the organization, becoming the only African country to remain outside of the organization. The paper will examine this unlikely occurrence and analyze the circumstances that led to Morocco's action. In this context, the paper illustrates the role played by the non-state actor (NSA) in Algeria and how it influenced the eventual withdrawal of Morocco from the OAU. In addition, the role of the NSA in Algeria was extremely important in indirectly undermining Morocco's foreign policy through the Western Sahara region. Since the conflict took place between Morocco and the Polisario Front in late 1975, the Algerian government has been the biggest supporter of the Polisario Front for Self-determination militarily, politically, financially, and diplomatically.

There's no doubt that Algeria 's involvement in the Western Sahara conflict has a long-term perspective especially geopolitical and economic terms not only regionally but also continently. As long as Algeria supported and lobbied for recognition of the Sahrawi Arab Democratic Republic (SADR) as a state, this reaction from Algeria was unacceptable by the Moroccan government and also the International society as a violation of international law and the rules of the United Nations. Finally, Algeria's strategies of a challenging the kingdom of Morocco are basically examined as to how its actions and moves have lessened Morocco's goals towards Western Sahara territory as well as the insight of Morocco within the Maghreb region and across the globe.

In line with investigating the relevant literature and examine the effectiveness and productivity of the interest group in influencing Moroccan foreign policy decisions through its territorial Western Sahara which is a business interest group. There requires to be an understanding of what exactly has been researched in regard to interest groups in terms of lobbying and impact on the interest in Moroccan Western Sahara. The core studies that have been done regarding the role played by non-state actors in influencing or affecting foreign policy can be divided into two main parts: the role played by external actors (NSA) in influencing foreign policy and the case of interest group in Algeria affecting Morocco's exit from the OAU. However, the interest group in Algeria tried to disrupt Morocco's foreign politics in relation to its domestic affairs on one hand and with its African partners on the other. Moreover, the interest groups were financed by the Sahrawi Nationalists in the Western Sahara region in order to gain more incentives and economic interests. the purpose of the paper is how non-state actors or interest groups are more influential in the region of Western Sahara as well as Northern Africa. Hence, the paper's independent variable lies within international politics' level, and since the objective of this paper is to show how this variable of Sahara case analysis Why and How interest group have impacted Morocco's foreign policy decision-makers over Sahara land, as well pointing out the strategic and dynamic Moroccan position on Western Sahara by addressing the international community and United Nations to stop Algerian involvement in other countries' internal affairs particularly Western Sahara territory. 


\section{Historical View of Western Sahara}

Western Sahara has been called the "old disputed desert" on the African continent. It is positioned in the northwest of Africa and it has nearly about 266,000 square kilometers of Sahara land. Geopolitically, Western Sahara is also rich in natural resources, for instance, having one of the biggest sources of phosphate ${ }^{15}$ in the world and offshore. Simultaneously, it is conspicuous about the possibility of oil and natural gas exploitation. Moreover, Western Sahara has more than 720 miles of coastline with rich fishing resources that have attracted stool pigeon islanders for many centuries. Not only economic but also political reasons, Moroccan nationalism is based on the "myth of recovering the lost territory of Moroccan Sahara" (Western Sahara) ${ }^{16}$ - it is hard for the Moroccan government to compromise a solution. Furthermore, because of the unique geopolitical interest of powerful states, particularly the United States and France, Morocco has continued the occupation of its lost territory without strong pressure from the international community. Historically speaking, Western Sahara was formally a Spanish colony known as Spanish Sahara. Before the Spanish colonization, there was no supra-tribal authority connecting to a large tribal network of the region. In fact, certain Saharan tribes, based on personal loyalty to the sultan or king, despite the sultan's religious authority, have contested the political authority of Moroccan dynasties in Western Sahara. After the Spanish recession from the region in1973, Morocco claimed sovereignty over the region. The Polisario Front was set up on 10th May 1973, and elated itself as the sole representative of the Sahrawi people, with support from the Algerian government and other African states. The Polisario claimed that the region was owned by Morocco. In 1884, during the pan-Arab Maghreb movement in the 1950s, Morocco engaged in a battle against French colonization and struggled for independence as "Arab Maghreb Unity" and at once, Algeria and Tunisia won independence as nation-states.

\section{The Conceptualization Analysis of Morocco and Algeria Relations and Chronological Conflict over Western Sahara}

Analyzing regional relations, it is irreplaceable to see how the Western Sahara impasse has conducted as regional conflict within several aspects. First, domestic, there is a component disagreement between Morocco and Sahrawi nationalists. Second, regional, the tension between Morocco and Algeria, regarding its support of the Polisario Front (SADR). Third, the transnational, international community have claimed to influence the peace process, either directly or indirectly. Due to these aspects, If we take a look at Morocco -Algeria relations towards the Western Sahara issue, we find out that Algeria tries to intervene in Morocco's domestic affairs, by influencing Moroccan foreign policy through its Western Sahara territory (by recognizing the SADR). On the one hand, from the Moroccan perspective, Western Sahara was carved out of Moroccan soil by the French colonial. Meanwhile, Algeria has proved formally that Western Sahara was non -self-governing territory since the former Spanish Sahara. On the other hand, from Algeria's side, the Western Sahara Dispute seems more politicalized. In fact, the Western Sahara dispute is typically a Moroccan-Algerian conflict, not Polisario's. Therefore, Sahrawi's nationalist would no longer exist if it were not for Algerian support and aid. For this reason, the kingdom of Morocco tries to negotiate with Algeria, not the Polisario Front.

More specifically, the two states' neighbors should promote urgent peace settlement to end the Western Sahara issue as African conflict and make an effective cooperation process of regional connectivity. Morocco stands ready to compromise extending diplomatic talks to Algeria and Polisario in a proper way under the principle of mutual cooperation and win-win outcomes not only to help Sahrawi people develop its integration and self -governing but also to gradually join Sahrawi people with Morocco through resolving Western Sahara dispute. Though, it was 12 years before Algeria formally decided to back the Polisario Front in 1975. From that time, the Kingdom of Morocco went to war against Algeria over the disputed border region. This impasse actually is all about Western Sahara especially when Algeria wants to have access to the Atlantic Ocean through the southern region of Morocco.

Accordingly, the impasse took another direction when the French Administration in Morocco and Algeria never set up a clear division of sovereignty until very late. Unclear border divisions of sovereignty were made by the French, so French colonial maps were even inconsistent, while French Administrative separations were basically mistaken for the outline of sovereignty particularity had seen as an effect of competition between the

\footnotetext{
${ }^{15}$ Morocco is one of world's largest exporters of phosphate (Europa Yearbook 1999).

${ }^{16}$ See, for instance, Jacob Mundy and Stephen Zunes, Western Sahara: War, Nationalism and Conflict Irresolution (Syracuse, NY: Syracuse Studies on Peace and Conflict, Resolution, 2010); Yahia H. Zoubir and Daniel Volman (eds.), The International Dimension of the Western Sahara Conflict (Westport, CT: Praeger, 1993); Ali Bahaijoub, Western Sahara Conflict: Historical, Regional and International Dimensions (London: North-South Books, 2010);
} 
French "protectorate" 17 of Morocco and a "colony "of Algeria. Consequently, the Kingdom of Morocco and Algerian borders suffered from several adjustments until the year 1901.

Since the Spanish troops withdrew from Western Sahara in 1973, the Algerian government started formally supporting the so-called Saharawi Arab Democratic Republic(SADR). Justifiably, what really motivated the Algerian government to support the Polisario Front was to undermine Moroccan foreign policy and reshape domestic politics towards the territory of Western Sahara. Besides, Algeria advocated Sahrawi's right to selfdetermination ${ }^{18}$ and it balloted all the UN resolutions pushing a referendum. To the extent, Algeria's support of Sahrawi people wasn't limited to political cooperation; it took too long that when Algeria gives military and logistical help to the Polisario Front (SADR) especially the sale of Soviet-made weapons (Hodges, 1983). As an Algerian regional supporter of the Polisario Front, the government supplied the SDR with weapons and money; therefore, there was a large profit to be made by the militarily from this monopoly. Algeria's back for Western Sahara's Polisario Front is precisely based on the natural resources and wanted to penetrate to the Atlantic sea in order to ease its export of mineral resources to the Americas, particularly Latin America. True, Algeria urged to propose a suggestion of the Self Determination as a settlement proposal to protect its own interests. Due to this, Algeria has a geographically suitable route from Tindouf (the area around the Algerian border) to the Atlantic Ocean not over Western Sahara, but in fact through to the seaport of Tarfaya (a town in the south of Morocco) (Damis, 1983 pp35). Additionally, Algeria has already exported mineral resources especially oil and gas to Europe using a pipeline runs through Moroccan territory, though suggesting that under this proposal "both sides are merely capable of separation between economic and political interests" (Zoubir, 1997 pp50).

Though controversial, between the two parties, a cease-fire between the Kingdom ${ }^{19}$ of Morocco and SADR was operated by the United Nations the Mission for the Referendum in Western Sahara (MINNURSO) ${ }^{20}$ and the Organization of African Unity (OAU), which came into effect on $6^{\text {th }}$ September 1991. This territorial dispute was addressed by the organization of African Unity (OAU). Mauritania gives up its share of the territory to Morocco, the organization actually was unable to assemble support for action through conflict. The Western Sahara crisis attributed to African infighting remained marginal with regard to global concern. After the failure of the OAU to resolve the impasse as part of its African Union duty, the UN waited to see what the OAU was going to do, and then the UN intervened to end the conflict by proposing a peace plan in the form of a "referendum".

Therefore, it has been almost half a decade since the Polisario right of self-determination was adopted by the UN. Even though the Sahrawi are struggling and waiting for the resolution, as noted above, the subjective circumstances of the impasse do not stand for a conclusion to be found. The recent movement of "the Gdeim Izik camp" event and the uncertainty of being linked with the AQIM might show that their patience has passed its limitation. If the related states pursue regional stability, first they should resolve the problems inside the region. As long as the Kingdom of Morocco and its neighbor (Algeria) end the negotiations on the issue, it will be hard to find a solution.

Table 1

\begin{tabular}{|c|l|}
\hline $\begin{array}{c}\text { 6th Sept, } \\
\mathbf{1 9 9 1}\end{array}$ & $\begin{array}{l}\text { A cease-fire is declared by Morocco and the Polisario. The UN pushes for a referendum } \\
\text { to determine the final status of Western Sahara. }\end{array}$ \\
\hline $\mathbf{1 9 9 1}$ & $\begin{array}{l}\text { Settlement Plan (Resolution 658) endorsed by the UN, proposing a referendum on } \\
\text { independence, autonomy or incorporation of Western Sahara. A vote never occurs. }\end{array}$ \\
\hline $\mathbf{1 9 9 7}$ & $\begin{array}{l}\text { Houston Agreement orchestrated by the UN to hold a vote in 1998. Morocco and the } \\
\text { Polisario disagree on how consensus is to be achieved and who counts as Sahrawi. A } \\
\text { vote never occurs. }\end{array}$ \\
\hline $\mathbf{2 0 0 1}$ & $\begin{array}{l}\text { Baker Plan I proposed, which would only allow Western Sahara autonomy. Algeria and } \\
\text { the Polisario reject the plan. }\end{array}$ \\
\hline
\end{tabular}

17 (1912). "Protectorate Treaty Between France and Morocco." The American Journal Law ,6(3).207-209.,

${ }^{18}$ Spector, S. (2009) "Western Sahara and the Self-Determination Debate."Middle East Quarterly", 19(3).33-43.

${ }^{19}$ Kingdom of Morocco (1/7/2013): http://www.maroc.ma/en/content/map-morocco.
20 Source:
International
Military
Operations
Training
Center

(28/7/2013):http://www.osrh.hr/smvo/Missions_en.asp?mission=MINURSO. 


\begin{tabular}{|c|c|}
\hline 2003 & $\begin{array}{l}\text { Baker Plan II proposed, creating a Western Sahara Authority which would govern for } \\
\text { five years before an autonomy vote would occur. Algeria and the Polisario agreed } \\
\text { eventually to the plan and the UN endorsed the plan, but Morocco rejected it due to the } \\
\text { possibility of } \\
\text { independence. }\end{array}$ \\
\hline May 2005 & $\begin{array}{l}\text { First Independence Intifada breaks out in Moroccan-held } \\
\text { Territories. }\end{array}$ \\
\hline $\begin{array}{l}\text { 9th Oct., } \\
2010\end{array}$ & Gdeim Izik set up by a protest camp in Western Sahara supported by Algeria. \\
\hline Feb 2011 & $\begin{array}{l}\text { A fresh round of protests in Western Sahara, inspired by both Gdeim Izik and the Arab } \\
\text { Spring protest movement. }\end{array}$ \\
\hline 2010-present & $\begin{array}{l}\text { Current UN Envoy Christopher Ross has held nine rounds of talks to bridge differences } \\
\text { between Morocco and the Polisario over any future settlement. Algeria and Mauritania } \\
\text { attend as observers. So far, nothing has happened to change Moroccan or Polisario } \\
\text { positions. }\end{array}$ \\
\hline
\end{tabular}

\section{1: This table shows Chronology of the Western Sahara Dispute \\ Source: Mundy. Book (2010) Western Sahara: War, Nationalism, and Conflict (Ir)resolution. Syracuse University Press.}

The aspect of the interest group has fired upon the state-centric international system. Though it has reshaped the role of international relations. Interest groups have forced a change in the types of sovereignty and also nationalism. These factors have influenced the role of the nation-states as the actors in the field of international relations. The actions, decisions, and policies of the nation-states recently touched upon the rising impact of the presence and activities of the interest groups so far. The latter has arisen as influential nonpolitical, economic, cultural and trading actors in the international sphere. Highlighting the role of an interest group or non-state actor, Intergovernmental Organization (IGOs) and Multinational Corporation (MNCs). Keohane and Nye (1971:330) have examined that these factors help to build up and enlarge the foreign policy agendas of national decisionmakers by serving as transmission belts by which one nation's policies become dedicated to another. Basically, the interest group is always seeking mutual benefits largely outside the direct control of nation-states. Thus, these involve governments in certain issues as outcomes of their activities.

Most interest groups are not organized well enough for political determinations and purposes. They often launch programs and spread information to enhance the professional, social, and business incentives of their members. Such interest group activities are non-governmental. For instance, the Algerian Oil Company "Numhyd ${ }^{21 "}$ provides low-cost life insurance for its lobbying ${ }^{22}$ members, in order to penetrate the political field to safeguard their oil interests or maintained the status quo that is anticipated to be more successful than their own policy orientation.

Recently the oil sector has become an attractive area for accessing and estimating the changing nature of oil business relations. companies like Numhyd Algerian Oil Company and Asmidal Petroleum Company have a

${ }^{21}$ John P. Entelis: Numhyd: The Political Economy of an Algerian State Institution Source: Middle East Journal, Vol. 53, No. 1 (Winter, 1999), pp. 9-27.

22 The OECD (2008) describes lobbying as the 'existence of powerful interests - corporate, private or other jurisdiction such as sub-national governments - that makes efforts to influence government decisions, in particular policy making, legislation or the award of contracts . 
large political influence among states that need external investment due to utilizing natural reserves, and longterm agreements give them significant finance within the anticipation of public goods and regulations among the state.

Numhyd is one of the largest Algerian oil firms in Africa along with very close ties to state politics. Indeed, Numhyd remains an important player in the oil industry in which stay nationalized. The Algerian Government owns Numhyd as the prior oil company in Algeria because of military generals and high ranking officials are stockholders. Numhyd informally can be used as a tool to disrupt other state's foreign policy especially seashore oil in the Western Sahara territory with Morocco in order to reach foreign policy outcomes. The Algerian government leads huge agitation to direct their alliance (African oil-producing countries such as Nigeria and Libya) against Morocco's position on Western Sahara. Yet, the black diamond is becoming a strategic commodity in the world economy and also its temptation of encouraging strategic partnerships to use. For example, Numhyd decided to raise oil output in North Africa and Latin America because Algeria's oil-based relationship with Libya keeps the Western Sahara issue unsolved, while Nigeria and other African states are partly politically motivated in this impasse. Consequently, examples of the Algerian national oil company in North Africa being connected to the geopolitical outcomes of their government. Algeria still using economic temptations, joint energy projects as well as lobbying OAU states and overseas for oil low pricing to win African influence.

Numhyd has used the potentiality of oil cut-offs to the OAU and some other Latin American States such as "Equator, Bolivia, and Venezuela" as a threat and sometimes deterrent to recognize the "SADR" Polisario Front as representative of Western Sahara; also they push them to cut their political ties with the Kingdom of Morocco. The same thing happened with Russia when it interrupted natural gas deliveries to Europe as a result of its dispute with members of the USSR charging oversupply prices and transport fees.

\section{Impact of interest group in Algeria on Morocco's decision to leave the OAU}

Since the Western Sahara tension started between Morocco and Algeria, the Maghreb world's attention has been focused on the prospects of the impact on Morocco's decision to quit the OAU. Fortunately, the governments of the two states have never lost their keen interests in holding negotiation which is seen as the fundamental feature of traditional diplomacy.

To the Interest groups, they are more interested in who was made more concessions, and therefore the benefit of the win impact on Western Sahara formula is a little bit irritable or unbelievable. After all, Algeria is in general powerful than SADR, particularly in terms of core military and technologies. Yet, the reality over the past years showed Morocco would not trade-off on its core legitimate territory no matter how desperately the Algerian or Polisario tries. What Algeria should and can do is to respect Morocco's territorial sovereignty and engage in consultations on an equal footing to quest a mutually acceptable resolution over Western Sahara. In return, due to the great regional partnership of centuries of historical cooperation and political opening-up, Morocco agrees to further open up its foreign diplomacy and negotiations with SADR so the Maghreb community including Algeria can benefit from its security and stable-developing arena. But Morocco will do so on its own circumstances, not to suit the agenda of other states (Algeria).

In view of Algeria. domestic opinion, there is still a decisive mood about long-term cooperation on regional diplomatic between Morocco and the Algerian government, even regarding some temporary difficulties between the two in the Western Sahara conflict. For example, at the first Rabat-Algeria talks, it reflected that despite the disputes at the moment, Algeria has a long-standing relationship with Morocco and the current politics would not break that, because it's really a political situation. Algeria further said the Polisario-Morocco territorial tensions are going to be a long-term disagreement in Polisario's relationship with Algeria, and the right of Selfdetermination would not impair the sharing of territory with Morocco. In the long-run, the diplomatic negotiations between the two parties are an opportunity to construct a new peace settlement if they have one compromise decision to end this impasse. Besides, the new head of the United National has long been an advocate for diplomatic negotiation and serious commitment and has frequently criticized AU's engagement approach. Upon taking the position, Guterres has referred to UNSC resolutions as a negotiating diplomatic consensus that refers to the accepted framework in which the settlement of conflicts through negotiation is only the legitimate tactic at reaching fairer diplomatic relationships.

In the doctrine of Interest groups, As "John Hassler Dietrich"23 mentioned that interest groups tactically are able to impact on the decision-making process made by foreign policymakers via three-dimensional levels:

The first level illustrates the position of the Organization of African Unity (OAU) through the Western Sahara file, as well as how the OAU has failed to resolve this impasse as an African issue. This creates a lack of trust among Morocco and the OAU in the sense of what the OAU can do over this territorial conflict which is

${ }^{23}$ Wikipedia John H. Dietrich: levels of Interests group, p 53. 
labeled as a forgotten case in the history of Africa. The second level is framing the impact of interest groups in Algeria on Morocco's decision to exit the OAU, and shape perspectives of the Algerian Government to disrupt Moroccan foreign policy towards its territory. Additionally, this level shows the development of the Polisario Front in the creation of the SADR and the rise of Algeria as the main supporter of this group over Western Sahara, Indeed, These interest groups have mobilized to represent a divergent batch of illegal business, labor, environmental, and other organizations. The third level, mention the rivalry and the hasty competition between the two states as hegemonic actors in the North African region.

Basically, the current situation of the Western Sahara dispute is really complicated. First of all, there is a big disagreement between the Kingdom of Morocco and Polisario (SADR) supported by both the International Court of Justice and the UNSC, on the status of Western Sahara. Secondly, there is an alternate between Rabat and neighboring states particularly Algeria and Libya, over their strong support for the so-called Polisario Front over Western Sahara, which is perceived as involvement in Moroccan domestic affairs. Therefore, the Western Sahara impasse has raised the question of the regional peace and stability of North Africa over many years. Thirdly, there is a disparate between the OAU and Morocco on the origin of the inviolability of so-called existing state frontiers and practically, the acceptance of the Polisario Front (SADR) as an OAU member state.

In effect, the OAU's attitude and its attachment to decolonization and inviolability of existing frontiers have guided the recognition of the Polisario Front as a sole representative of Western Sahara territory and to the withdrawal of Morocco from the African Organization. In fact, several OAU state members have unresolved border conflicts, and the Western Sahara case might be the most complex one over Northern Africa; besides, the Western Sahara dispute becomes the largest context of the Arab world.

True, The involvement of the OAU in cooperation with the UN mission to compromise a settlement process in Western Sahara issue was one of the OAU's priorities of accepting the so-called "Referendum" in Sahara region which was launched in 1991 to supervise an uneasy cease-fire between Morocco and the Polisario Front and hold a referendum to give the green light to Sahrawi's nationalists to ballot for either Moroccan integrity or self-determination ${ }^{24}$ of Western Sahara. However, the OAU and Morocco relationships were a bit fussy to achieve a resolution of the Sahara quarrel. Morocco formally withdrew from the OAU in 1984 over the recognition of Sahrawi Arab Democratic Republic (SADR) which indeed Morocco has rejected (SADR) persistently. For 30 years, the Kingdom of Morocco has not rejoined the OAU ${ }^{25}$ and remains out of the Unity unless the derecognize membership of SADR.

Accordingly, the transnational conflict in Africa's Sahel region, followed by the French intervention in Mali, has shed light on the stalemate over Western Sahara, which has been afoot in regional power playing for several years. For instance, the "distance" among African relations built up by Morocco's absence from the OAU, this latter is pursuing deeper integration in the Atlantic sphere and strengthening of its European links, but this won't be in OAU's anticipation or Africa's interests. Inside Morocco, the internal reform could enlarge the 2007 Autonomy Proposal for Western Sahara and help understanding questions concerning its viability. For Moroccan investment in Western Sahara territory and concerted efforts to call up a Sahrawi elite into the establishment, there is no existence escape of a powerful nationalist perception on the ground of an occupation. As long as the OAU's statements are regularly explicit it does show that Morocco may try to rethink the key arrangement in the autonomy proposal to oppose the powerful position of self-determination.

For sure, OAU has failed to cure and rectify the Western Sahara deadlock as a frozen impasse in Africa. if OAU engaged in and interacted meaningfully, the OAU must check the Kingdom of Morocco, Polisario Front (SADR) and perhaps Algeria as SADR's main advocate, with the recent notion and conception to compromise peace process over Western Sahara. Morocco's continuing absence from (OAU) does not jeopardize constructing a permanent break in the organization but restricts its position and role in Africa's economic growth and expansion, which Morocco, given its approximate integration with the European and the Mediterranean vessel, is particularly well placed to play.

\section{Conclusion}

In sum, it is necessary to be aware that Algeria is still the key player in the region including the Western Sahara issue, its involvement in manipulating the interest group as a means to weaken Morocco's foreign policy and geopolitical interests. This illegal involvement of Algeria in Morocco's internal affairs will definitely create

\footnotetext{
${ }^{24}$ Malcolm Shaw, Title to Territory in Africa: International Legal Issues (New York, 1986), p. 124; cited in Susan Slyomovics, "Self-Determination as Self-Definition: The Case of Morocco", in Hurst Hannum and Eileen F. Babbitt (eds.),Negotiating Self-Determination (Lanham, Boulder, New York, Toronto, Oxford, 2006), pp. 135-157.

${ }^{25}$ Nora McKeon :" The African States and the OAU" Source: International Affairs (Royal Institute of International Affairs 1944-), Vol. 42, No. 3 (Jul., 1966), pp. 390-409 .
} 
serious tension ${ }^{26}$. Moreover, on the current ease of tensions on the Sahara impasse, it is self-evident that Morocco's suspension-for proposal has worked. Moroccan government stated that Morocco's proposal has proven to be the right convention for the issue as it has created the basic circumstances needed for improving inter-Algeria relations. In order to move forward negotiations on the Western Sahara issue, Morocco has pushed that a self-government or "Autonomy Proposal" serves the interests of all parties, including Moroccans and Sahrawi people. Yet, due to this, all concerned parties should illustrate their commitment to resolving the conflict and bring the circumstances back to the path of peaceful dialogue and negotiations.

The Western Sahara crisis needs an integral process based on negotiation, persuasion, and compromise. On the one hand, this tension will end up destabilizing North Africa and Maghreb regions. a stable Algeria -Morocco political relationship is crucial for both and the African world as a whole. Consider all these, Morocco is proposed to use all funds to increase extensive strategic partnership with Algeria and particularly Polisario (SADR), to promote a sustainable peace process to end this conflict.

\section{References}

Arts, K. \& Leite, P.P. (ed) (2007): International Law and the Question of Western Sahara. Leiden, the Netherlands: International Platform of Jurists for East Timor (IPJET).

Anderson, Lisa. 1997. Prospects for Liberalism in North Africa: Identities and Interests in the Preindustrial Welfare States. In Islam, Democracy and the State in North Africa,[M], John Entelis ed., 127-140. Indianapolis: Indiana University Press.

Clapham, A (2006) "Human Rights Obligations of non-state actors in conflict situations", in International Review of the Red Cross. Vol.88/No.863/Sept.2006.

Council of Ethics, "Advice to refrain from investing in Western Sahara - Letter to the Ministry of Finance". Available: http://www.regjeringen.no/nb/dep/fin/tema/statens pensjonsfond/ansvarligeinvesteringer/tilradninger-og-brev-fra-etikkradet/tilradning-om-uttrekk2.html?id=91683 [Accessed on: June 06.2005].

Damis, John (1983) conflict in Northwest Africa-The Western Sahara Dispute. [M], Hoover Institution Press, Stanford University, California.

Gordon Harris: "Organization of African Unity" [J], (International Organizations; Series: Vol .7) Title II. series 341.249, ISBN 1-85109-124-6. CLIO Press. Oxford. England.

Malcolm Shaw, Title to Territory in Africa: International Legal Issues (New York, 1986), p. 124; cited in Susan Slyomovics, "Self-Determination as Self-Definition: The Case of Morocco", [M], in Hurst Hannum and Eileen F. Babbitt (eds.), Negotiating Self-Determination (Lanham, Boulder, New York, Toronto,[M], Oxford, 2006), pp. 135-157.

Maghraoui, A. (2003) "Ambiguities of Sovereignty: Morocco, The Hague, and the Western Sahara Dispute."[J], Mediterranean Politics, 8 (1)., 113-126.

Mundy, J. (2007) “Negotiations in Western Sahara: [J], The UN's Last Chance?” Review of African Political Economy, 34(114). 730-735.

Marks, T. (1976). "Spanish Sahara - Background to Conflict." [J], African Affairs, 75(298.).

Nora McKeon: "The African States and the $O A U$ " Source: International Affairs (Royal Institute of International Affairs 1944-), Vol. 42, No. 3 (Jul., 1966), pp. 390-409.

"Numhyd -Fields Development Background," [J], Arab Press Service Organization, APS Review Oil Market Trends 44, no. 3 (23 January 1995), pp. 17-18.

Parker, Richard B. 1987.[M], North Africa: Regional Tensions and Strategic Concerns. New York: Praeger.

Scott H. Ainsworth: The Role of Legislators in the Determination of Interest Group Influence Legislative Studies Quarterly, Vol. 22, No. 4 (Nov. 1997), pp. 517-533 Published by Comparative Legislative Research Center.

See.https://moderndiplomacy.eu/2019/03/31/western-Sahara-round-3-into-the-final-solution/.[Accessed on: March 31 2019].

Terence McNamee, 'Managing the Two Solitudes: Lessons from Canada', in Jeffrey Herbst, Terence McNamee and Greg Mills (eds.), On the Fault Line: Managing Divisions and Tensions in Societies,[M] (London: Profile Books, 2012). A chapter on the FL.

Terence McNamee, Greg Mills, and J. Peter Pham, "Morocco and the African Union": Prospects for Reengagement and progress on Western Sahara. Published by The Brenthurst Foundation in February 2013,[M] Johannesburg 2000, South Africa.

Western Sahara:" Business Law Handbook". Vol 1; Strategic Information and Basic Laws .2013 Edition Updated

\footnotetext{
${ }^{26}$ Parker, Richard B. 1987. North Africa: Regional Tensions and Strategic Concerns. New York: Praeger.
} 
Reprint International Business Publications, US. ISBN No: 1-4387-7142-8.[M], Published by International Business Publication, Washington DC. 2003.

Werenfels, I. 2007. Managing Instability in Algeria: Elites and Political Change since 1995. [M], London and New York: Routledge.

Yahia Zoubir and Gregory White: "North African Politics: Change and continuity" [J], First Published 2016 by Routledge. ISBN 978-1-138-92294-5 (hbk). Routledge and Francis Group, Oxon. OX 14.4 RN. New York. 2016.

Zunes, S. and J. Mundy (2010) Western Sahara: War, Nationalism, and Conflict [M](Ir)resolution. Syracuse University - Press. 